\title{
E-LEARNING EDMODO DENGAN MODEL PBL UNTUK MENINGKATKAN MINAT BELAJAR SISWA PADA MASA PANDEMI COVID-19
}

Ervan Johan Wicaksana ${ }^{1 *}$, Pramana Atmaja ${ }^{2}$, Gusti Ayu Muthia ${ }^{1}$

${ }^{1}$ Universitas Jambi, Jambi, Indonesia

2 Universitas PGRI Madiun, Jawa Timur, Indonesia

* corresponding author | email : ervan_jw@unja.ac.id

Penelitian ini bertujuan untuk meningkatkan minat belajar siswa melalui penerapan E-Learning Edmodo dengan model pembeajaran PBL selama masa pandemi Covid-19 ini. Dalam studi pendahuluan yang dilakukan kepada siswa MAN 2 kota Jambi yang melakukan kegiatan pembelajaran selama pandemi Covid-19 menyatakan bahwa minat belajarnya rendah. Hal ini terjadi karena guru hanya memberikan tugas dan tidak ada proses pembelajaran yang menghubungkan langsung antara guru dan siswa melalui suatu kegiatan pembelajaran dan penggunaan platform Edmodo masih jarang digunakan. Pengambilan data dilakukan dengan menggunakan google form yang berisi kuesioner tentang tanggapan deskripsi kegiatan menggunakan edmodo kepada siswa kelas XI. Hasil peningkatan minat siswa berdasarkan beberapa indikator yang diamati adalah rasa senang dengan skor rata-rata 3,18 termasuk kategori baik, keingintahuan 3,38 kategori sangat baik, perhatian 3,30 kategori sangat baik, dan ketertarikan 3,015 kaategori baik. Berdasarkan data penelitian diketahui bahwa penerapan pembelajaran Problem Based Learning selama pembelajaran menggunakan elearning edmodo mampu meningkatkan minat belajar siswa.
\end{abstract}

\section{Kata Kunci : e-learning, Edmodo, PBL, minat belajar}

This study aims to increase students' interest in learning through the application of Edmodo E-Learning with PBLlearning models during the Covid-19 pandemic. In a preliminary study conducted to MAN 2 students in Jambi City who conducted learning activities during the Covid-19 pandemic stated that their interest in learning was low. This happens because the teacher only gives assignments and there is no learning process that connects directly between the teacher and students through a learning activity and the use of Edmodo platform is still rarely used. Data was collected using a google form containing a questionnaire about responses to descriptions of activities using Edmodo to class XI students. The results of increasing student interest based on several indicators observed were happy with an average score of 3.18 including the good category, curiosity 3.38 the excellent category, the attention of 3.30 the excellent category, and the interest of the 3015 good category. Based on research data it is known that the application of Problem Based Learning during learning using ed-modo e-learning can increase student interest in learning. 
Peyebaran wabah Corona virus deseases (Covid-19) menyebar dengan sangat cepat bagi ke seluruh daerah yang ada di dunia sehingga menimbulkan kecemasan dan keresahan oleh orang-orang di berbagai belahan dunia. Virus ini awalnya muncul dari Wuhan Cina sejak akhir Januari 2020. Organisasi kesehatan dunia (WHO) memberikan fakta yang menyatakan bahwa wabah Covid-19 sebagai darurat kesehatan masyarakat atau disebut juga pandemic (Mahase, 2020).

Persebaran Covid-19 yang begitu cepat ini menyebabkan berbagai Negara terpaksa untuk melihat keadaan bahwa keadaan dunia telah berubah. Hal ini karena Covid-19 menyebabkan perubahan terhadap ekonomi, social, politik, hukum, hingga pendidikan pun ikut berubah. Salah satu upaya untuk pencegahan penyebaran Covid-19 di lingkungan pendidikan, kementrian pendidikan dan kebudayaan, merespon dengan kebijakan "belajar di rumah". Melalui pembelajaran daring dan menentukan kebijakan untuk meniadakan ujian nasional pada tahun ini (Kemendikbud. 2020). Namun faktanya masih terdapat cukup banyak tenaga pengajar yang belum menggunakan media pembelajaran berbasis ICT ini dalam menyampaikan materi pengajarannya (Rosdiana, 2018:74)

Dampak dari kebijakan ini membuat para tenaga pendidik (guru/dosen) menjadi panik dan kaget karena mereka harus mengubah metode, dan sistem pembelajaran mereka. Model pembelajaran ditengah-tengah kepemilikan sarana pendukung internet komputer dan sejenisnya untuk melaksanakan sistem daring belum memadai memadai secara individu maupun kelembagaan. Mayoritas pendidik masih beranggapan bahwa pendidik adalah factor kunci dalam menentukan keberhasilan pembelajaran. Menurut (Wicaksana \& Pramana, 2018) animo belajar peserta didik sebesar $28 \%$ dipengaruhi oleh adanya guru. Hal membuktikan bahwa masih banyak lagi faktor lain yang mempengaruhi animo belajar peserta didik, salah satunya dengan menggunakan media pembelajaran ICT. Fenomena ini menjadi catatan penting untuk dunia pendidikan di Indonesia yang dituntut harus siap mengajar dan belajar secara online (daring) yang syarat kompetensi cermat, cepat, dan tepat. Parray (2017) pernah berpesan kepada Indonesia untuk meningkatkan keterampilan tenaga kerja dengan teknologi digital. Yang dimaksud dengan tenaga kerja di atas adalah termasuk tenaga kerja dibidang pendidikan, salah satunya guru dan dosen.

Menurut angket studi pendahuluan yang disebarkan kepada peserta didik yang melakukan kegiatan pembelajaran di selama pandemi Covid-19 menyatakan bahwa minat belajarnya rendah. Hal ini terjadi karena guru hanya memberikan tugas dan tidak ada proses pembelajaran yang menghubungkan langsung antara guru dan siswa melalui suatu kegiatan pembelajaran. Salah satu cara untuk meningkatkan minat belajar selama pembelajaran siswa di rumah adalah memanfaatkan media e-learning yang dapat menghubungkan siswa dan guru agar terjadi proses pembelajaran tetap berlangsung meskipun tanpa tatap muka

Menurut Pratiwi (2015) minat belajar perlu mendapatkan perhatian khusus karena minat belajar merupakan salah satu faktor yang dapat menunjang keberhasilan belajar. Siswa akan belajar dengan baik apabila memiliki minat belajar yang besar. Jika memiliki minat belajar yang tinggi maka siswa akan memperbaiki kegiatan pembelajaranya. Siswa tersebut akan aktif dan jika tidak memahami pembelajaran siswa akan bertanya. Sebaliknya jika memliki minat yang rendah siswa cenderung kurang aktif dan berdampak terhadap hasil belajar yang diperolehnya. Menurut (Wicaksana, E.J., 2020) sebesar $25 \%$ peserta didik termotivasi dan $62 \%$ sangat termotivasi dalam pembelajaran daring dengan menggunakan ICT walaupun disaat pandemic covid-19. Peran ICT di bidang pendidikan sangat dibutuhkan yaitu dengan penggunaan media pembelajaran yang memanfaatkan ICT.

Salah satu upaya untuk meningkatkan minat belajar yaitu dapat dengan menerapkan ICT berbasis E-learning. Salah satunya adalah dengan edmodo yang dapat dikombinasikan dengan model pembelajaran. Diperlukan model pembelajaran yang fleksibel dalam pembelajaran daring, salah satunya adalah PBL yang dapat membantu siswa dalam belajar menggunakan e-learning. E-learning menurut Yazdi (2012) merupakan penggunaan teknologi seperti internet yang dimanfaatkan untuk memberikan informasi berupa solusi yang dapat meningkatkan pengetahuan dan keterampilan. Elearning memiliki fleksibelitas dalam pengolahanya meskipun terbatas dengan kemampuan keberadaan jaringan internet itu sendiri (Aminoto \& Pathoni, 2015). Selain itu, e-learning memiliki potensi untuk membuat pembelajaran menjadi lebih efektif karena peluang interaksi antara siswa dan 
guru maupun bahan belajarnya terbuka luas. Karena siswa dapat berkomunikasi dengan guru kapan saja dan dimana saja (Chandrawati, 2010).

Edmodo merupakan salah satu aplikasi yang didukung oleh fasilitas internet yang memadahi. Edmodo merupakan salah satu media E-Learning berbasis social network seperti halnya facebook, twitter dan lain sebagainya dengan penggunaan yang mudah (Istiqomah \& Azizah, 2013). Edmodo menurut Angraini, Muharini and Lestari (2018) juga memungkinkan siswa untuk mengakses konten pembelajaran yang diunggah (bahan-bahan pembelajaran, link, video pembelajaran, penugasan, dan pemberitahuan nilai) oleh guru serta mempermudah guru dan siswa berkomunkasi dalam lingkungan kelas online.

Menurut Putranti (2013) edmodo merupakan situs pembelajaran yang terjamin keamananya untuk digunakan oleh guru, siswa dan sekolah berbasis social media. Edmodo juga termasuk kedalam sebuah Learning Management System yang dapat memfasilitasi guru untuk mengatur kelas online secara mudah (Marzal, 2014). Selain itu, edmodo sangat berguna dalam memfasilitasi kegiatan belajar mengajar karena edmodo meningkatkan interaksi dimanapun siswa berada tetap dapat terjadi interaksi secara langsung melalui edmodo ini, sehingga siswa tidak takut mengekspresikan bahkan berbagi pendapat mereka tanpa disalahkan oleh orang lain (Monalisa \& Havid Ardi, 2013).

Penelitian-penelitian sebelumnya yang menggunakan aplikasi Edmodo di dalam proses pembelajaran menggunakan Edmodo menyatakan bahwa Edmodo dapat menyebabkan siswa lebih berpartisipasi dalam pembelajaran dan merupakan alat yang produktif yang memungkinkan siswa untuk mudah berinteraksi dalam dunia pendidikan (Gushiken, 2013). Edmodo ini layak digunakan sebagai media pembelajaran yang efektif terhadap minat dan hasil belajar siswa (Hikmah, 2017).

Pengalaman belajar hendaknya diintegrasikan dengan kecakapan hidup (life skill) yang memberikan bekal kepada siswa dalam berbagai aspek kehidupan. Salah satu aspek kedalam kecakapan hidup adalah menyisipkan keterampilan hidup pada media pembelajaran pembelajaran (Wicaksana, E.J, Maridi., 2017). Model Pembelajaran yang dapat mengakomodir hal tersebut adalah Problem based learning. Penerarapan model pembelajaran Problem Based Learning membuat siswa menjadi lebih efektif dalam memahami materi, menantang kemampuan siswa, serta memberikan kepuasan untuk menemukan pengetahuan baru bagi siswa (Suparya, 2020). Adapun langkah-langkah dari pendekata PBL yaitu, orientasi siswa pada masalah, membimbing pengalaman individual atau kelompok, mendorong siswa untuk megumpulkan informasi yang sesuia, melaksabakan eksperimen untuk memecahkan masalah, mengembangkan dan menyajikan hasil karya (Rahmadani \& Anugraheni, 2017)

Adapun Landasan teori dari PBL adalah kolaborativisme, merupakan suatu perspektif bahwa siswa akan menyusun pengetahuan dengan cara membangun penalaran dari semua yang dimilikinya sehingga proses konstruksi pengetahuan yang sifatnya social dan individual (Sudarman, 2007). Dalam menerapkan pendekatan PBL sumber belajar tidak hanya diambil dari satu sumber belajar saja, dan pendekatan PBL mengutamakan belajar mandiri (siswa aktif), solusi yang didapatkan siswa dikomunikasikan di depan kelas (Anugraheni, 2018).

Berdasarkan hal ini diharapkan dengan Penerapan E-Learning Edmodo dengan Model Pembelajaran Problem Based Learning dapat meningkatkan minat belajar Siswa. Hasil penelitian ini dapat bermanfaat untukmenambah khazanah ilmu tentang proses pembelajaran dan diharapkan dapat mengtasi masalah yang terjadi di dalam kelas.

\section{METODE}

Jenis penelitian ini termasuk ke dalam jenis penelitian tindakan kelas yaitu suatu pengamatan penelitian yang dilakukan pada suatu kelas menggunakan kegiatan pembelajaran yang sudah direncanakan dengan baik sebelum tindakan tersebut dilakukan. Akan tetapi, penelitian ini hanyalah penelitian mini riset dari penelitian tindakan kelas dimana kegiatan pembelajaran tidak benar-benar dilakukan, namun hanya berupa rencana kegiatan pembelajaran yang akan dilakukan di kelas.

Metode penelitian yang digunakan adalah penelitian kualitatif dengan analisis deskriptif 
mengunakan angket likert. Pengambilan data dengan questioner dilakukan dengan beberapa pernyataan tertulis terhadap responden untuk memperoleh tentang minat belajar siswa. Adapun angket dalam penelitian ini berjumlah 10 butir pertanyaan. Adapun indikator dari butir soal untuk melihat peningkatan minat siswa dilihat dari beberapa indicator yaitu rasa senang, keingintahuan, perhatian dan ketertarikan. Angket likert dibuat menggunakan skala 4 (empat) yaitu: Sangat Setuju (SS), Setuju (S), Tidak Setuju (TS), dan Sangat Tidak Setuju (STS) sesuai pada Tabel 1.

Tabel 1. Kisi-kisi instrumen

\begin{tabular}{llrr}
\hline Variabel & Indikator & Butir Soal & Jumlah \\
\hline Minat Belajar & Rasa senang & $1,2,3$ & 3 \\
\cline { 2 - 4 } & Keingintahuan & 4,5 & 2 \\
\cline { 2 - 4 } & Perhatian & $6,7,8$ & 3 \\
\cline { 2 - 4 } & ketertarikan & 9,10 & 2 \\
\cline { 2 - 4 } & Jumlah & & 10 \\
\hline
\end{tabular}

(Hidayatullah, 2018)

Subjek penelitian dalam pemberian angket ini adalah siswa MAN 2 Kelas XI. Angket pertama yang merupakan studi pendahuluan merupakan angket mengenai keadaan minat belajar siswa selama pembelajaran di rumah yang dilakukan. Untuk mendapatkan data awal pengamatan bagaimana keadaan minat belajarnya. Setelah itu, dibuat angket kedua yang berisi deskripsi kegiatan pembelajaran baru dan melihat bagaimana peningkatan minat belajarnya dengan 10 butir soal yang tersedia. Dan tambahan kritik dan saran terhadap deskripsi kegiatan pembelajaran. Butir soal juga dilakukan uji validitas dan reliabilitasnya menggunakan SPSS versi 22 for windows. menunjukkan bahwa instrument yang dibuat mengukur apa yang seharusnya diukur di dalam penelitian dan apabila digunakan beberapa kali untuk mengukur objek yang sama akan menghasilkan data yang sama (Sugiyono, 2013).

\section{HASIL DAN PEMBAHASAN}

Instrumen penelitian yang digunakan berupa instrument angket untuk melihat bagaimana minat belajar siswa selama pembelajaran online di rumah pada masa pandemic Covid-19 ini. Adapun indicator yang diamati dari minat belajar siswa adalah rasa senang, keingintahuan, perhatian, dan ketertarikan dalam pembelajaran menggunakan Model pembelajaran dengan bantuan e-learning edmodo. Angket ini diberikan kepada 30 siswa yang ada di kelas XI. Berikut in adalah hasil deskripsi tabel tanggapan responden (siswa) terhadap pembelajaran dalam meningkatkan minat yaitu sebagai berikut pada Tabel 2 .

Tabel. 2 Rata-rata skor dalam setiap indikator minat belajar siswa

\begin{tabular}{lll}
\hline Indikator & rata-rata & Kategori \\
\hline Rasa senang & 3,18 & Baik \\
keingintahuan & 3,38 & Sangat Baik \\
Perhatian & 3,3 & Sangat Baik \\
ketertarikan & 3,015 & Baik \\
\hline Total Skor & 3,34 & Sangat Baik \\
\hline
\end{tabular}

Berdasarkan variabel minat belajar yang terdiri dari 4 indikator dimana tiap indicator terdiri dari 3 atau 2 soal. Pada Tabel 2 menunjukkan bahwa total skor rata-rata jawaban responden terhada pernyataan dari keseluruhan indicator variabel minat belajar ini sebesar 3,34 yang menunjukkan bahwa variabel minat belajar siswa termasuk ke dalam kategori sangat baik. Skor rata-rata tertinggi yang diperoleh melalui indikator minat belajar siswa ini sebesar 3,38 dari keingintahuan siswa terhadap pembelajaran sedangkan skor rata-rata terendah diperoleh sebesar 3,015 dari ketertarikannya terhadap pembelajaran. Uji realibilitas dan validitas tiap butir soal dengan 
penyebaran angket kepada dilakukan kepada 30 responden siswa dengan menggunakan taraf signifikan sebesar $5 \%$ sehingga diperoleh $r$ (tabel) sebesar 0,361 . Didapatkan bahwa tiap butir soal valid dan reliabel.

Pada hasil analiss deskriptif berdasarkan instrument tanggapan terhadap variabel Minat belajar siswa. Minat belajar merupakan hal yang penting dalam proses pembelajaran karena minat merupakan salah satu faktor internal yang mempengaruhi pembelajaran. Instrument yang digunakan untuk menentukan minat belajar siswa terdiri dari 10 butir soal yang berupa 4 indikator yang diamati yaitu rasa senang, keingintahuan, perhatian, dan ketertarikan. Berdasarkan rata-rata dari tabel analisis hasil dari instrument likert didapatkan rata-rata keseluruhan minat belajar siswa yaitu 3,34 dengan kategori sangat baik.

Berdasarkan tabel 2 yang menunjukkan dalam setiap kondisi rata-rata siswa minat belajarnya sangat baik dengan penerapan kegiatan pembelajaran ini. Rasa senang siswa dalam belajar memiliki rata-rata skor 3,18 termasuk ke dalam kategori baik. Hal ini menunjukkan bahwa siswa merasa senang dengan pembelajaran menggunakan model pembelajaran Problem Based Learning melalui e-learning edmodo, dan ingin memanfaatkan waktunya untuk belajar. Indikator keingintahuan memiliki rata-rata skor paling tinggi diantara indikator lainya yaitu 3,38 dengan kategori sangat baik. Berdasarkan hal ini menunjukkan bahwa penerapan pembelajaran membuat siswa memperhatikan materi pembelajaran yang diberikan dan adanya keinginan untuk mecari tahu lebih dalam terhadap materi yang diberikan. Perhatian siswa dalam belajar memiliki rata-rata 3,3 dengan kaegori sangat baik. Perhatian ini hampir sama dengan keingintahuan dimana perhatian ini membuat siswa berkeinginan untuk memperhatikan materi pembelajaran, menghabiskan waktunya untuk memahami pembelajaran dan menemukan sendiri materi yang diberikan. Kondisi yang terakhir adalah ketertarikan. Ketertarikan siswa menggunaan pembelajaran ini memiliki nilai rata-rata terendah yaitu sebesar 3,015 termasuk kategori baik.

Perbandingan tiap kondisi berdasarkan skor yang diperoleh menunjukkan bahwa keingintahuan merupakan bagian dari indicator tertinggi dalam meningkatkan minat belajar siswa. Penerapan model pembelajaran Problem Based Learning melalui e-learning edmodo bisa berdampak terhadap minat belajar siswa. Menurut Vania et al (2018) minat belajar dan motivasi dapat menjadi alasan seorang individu mengambil tindakan. Minat dalam belajar akan menunjukkan keiginan untuk memperoleh informasi, mengembangkan kemampuan atau keterampilan dan mampu menguasai pengetahuan tersebut. Ketertarikan siswa dalam menggunakan media pembelajaran menggunakan software lebih besar dibandingkan ketertarikan atau minat belajarnya secara tradisional di kelas. Pemanfaatan potensi teknologi menggunakan edmodo memberikan pengaruh secara positif kepada siswa.

Hasil penelitian ini mennjukkan bahwa Problem Based Learning melalui e-learing edmodo dapat berpengaruh secara positif terhadap minat belajar siswa. Artinya semakin menarik rencana pembelajaran yang dibuat dalam proses pembelajaran secara daring (e-learning) ini maka akan semakin baik ketertarikan siswa dalam pembelajaran. Hasil penelitian ini didukung oleh penelitian yang pernah dilakukan sebelumnya seperti pada penelitian Yustinaningrum (2018) yang menyatakan bahwa minat belajar dapat meningkat dengan adanya penerapan pembelajaran dengan menggunakan edmodo dengan peningkatan minat belajar sebeesar $76 \%$. Penggunaan edmodo dapat menjadi media aplikasi untuk melatih siswa belajar secara mandiri, membuat siswa aktif mencari sumber materi sebelum pembelajaran, melakukan diskusi online tentang tugas yang diberikan, dan menyelesaikan tugas tepat waktu.

Penelitian yang dilakukan oleh Aulia et al (2019) Penggunaan media Edmodo memudahkan siswa dalam melaksankan pembelajaran problem-based learning. Hal tersebut ditunjukkan dengan meningkatnya kemandirian belajar siswa sehingga edmodo dapat dijadikan salah satu alternatif untuk diterapkan dalam pembelajaran.

Menurut Nu'man (2013) juga menunjukkan bahwa pemanfaatan e-learning edmodo dalam proses pembelajaran efektif untuk meningkatkan keaktifan belajar siswa. Siswa yang aktif merupakan indicator adanya peningkatan minat belajar siswa karena adanya rasa senang, perhatian, keingintahuan, serta ketertarikan dalam belajar sehingga meningkatkan hasil belajarnya. Penelitian 
Saugi (2018) juga menunjukkan bahwa penggunaan edmodo dapat meningkatkan minat belajar siswa yang ditandai dengan meningkatnya hasil belajar siswa yang signifikan berdasarkan uji pre-test dan post-test.

Penerapan model pembelajaran Problem Based Learning selama pembelajaran menggunakan elearning edmodo memberikan keleluasaan bagi siswa untu belajar, mengerjakan tugas dimanapun dan kapanpun mereka berada tanpa adanya batasan ruang dan waktu. Keleluasaan ini dapat membuat siswa lebih antusias dalam belajar menggunakan perangkat teknologi seperti laptop, handphone ataupun computer selama proses pembelajaran. Dalam meningkatkan minat belajar penerapan Problem Based Learning selama pembelajaran menggunakan e-learning edmodo memberikan kesempatan seluas-luasnya kepada siswa untuk mengaktualisasikan diri mereka dalam proses pembelajaran. Aktualisasi diri inilah yang dapat menjadi menyebabkan dorongan kuat untuk melaksanakan pembelajaran yang optimal (Suparya, 2020).

\section{KESIMPULAN DAN SARAN}

\section{Kesimpulan}

Berdasarkan hasil penelitian dan pembahasan yang telah dilakukan dapat ditarik kesimpulan bahwa penerapan model pembelajaran Problem Based Learning melalui e-learning edmodo dapat meningkatkan minat belajar siswa. Penerapan pembelajaran Problem Based Learning selama pembelajaran menggunakan e-learning edmodo mampu meningkatkan minat belajar siswa dengan memberikan kesempatan seluas-luasnya kepada siswa untuk mengaktualisasikan diri mereka dalam proses pembelajaran.

\section{Saran}

Penelitian ini diperlukan adanya kajian lebih mendalam karena penelitian ini hanya dilakukan berdasarkan pendapat siswa melalui angket google form dan sumber permasalahan juga berdasarkan instrument angket google form. Berdasarkan kritik dan saran dari google form banyak siswa yang tetap ingin melaksanakan pembelajaran tatap muka agar dapat lebih leluasa bertanya dan menghindari terjadinya miskonsepsi, dan perlunya media pembelajaran yang menarik yang ditampilkan di edmodo sehingga dapat meningkatkan minat belajar siswa. Akan tetapi karena keadaan, pandemic ini penerapan pembelajaran ini dapat berjalan dengan baik jika guru dapat merencanakan kegiatan pembelajaran dengan baik.

\section{DAFTAR RUJUKAN}

Aminoto, T., \& Pathoni, H. (2015). Penerapan Media E-Learning Berbasis Schoology Untuk Meningkatkan Aktivitas dan Hasil Belajar Materi Usaha dan Energi Di Kelas XI SMA N 10 Kota Jambi. Jurnal Sainmatika, 8(1), 13-29.

Angraini, M. R., Muharini, R., \& Lestari, I. (2018). Penerapan Blended Learnng Berbasis Edmodo Terhadap Minat dan Hasil Belajar Siswa SMA Negeri 9 Pontianak. Jurnal Pendidikan Dan Pembelajaran Khatulistiwa, 7(2), 1-12.

Anugraheni, I. (2018). Meta Analisis Model Pembelajaran Problem Based Learning dalam Meningkatkan Keterampilan Berpikir Kritis di Sekolah Dasar. Meta Analisis Model Pembelajaran Problem Based Learning Dalam Meningkatkan Keterampilan Berpikir Kritis Di Sekolah Dasar, 14(1), 9-18.

Aulia, L. N., Susilo, S., \& Subali, B. (2019). Upaya peningkatan kemandirian belajar siswa dengan model problem-based learning berbantuan media Edmodo. Jurnal Inovasi Pendidikan IPA, 5(1), 69-78. https://doi.org/10.21831/jipi.v5i1.18707

Chandrawati, S. R. (2010). Pemamfaatan E-Learning Dalam Pembelajaran. Jurnal Cakrawala Kependidikan, 8(2), 172-181.

Gushiken, B. K. (2013). Integrating Edmodo into a High School Service Club : To Promote Interactive Online Communication. In TCC Worldwide Online Conference (pp. 1-6). USA: 18 Th.

Hidayatullah. (2018). Penelitian Tindakan Kelas. Banten: LKP Setia Budi. 
Hikmah, N. (2017). Efektivitas Media Pembelajaran Edmodo Terhadap Minat Belajar Dan Hasil Belajar Siswa Pada Materi Fisika Kelas Xi Ipa Sman 1 Tanete Rilau Skripsi. Skripsi.

Istiqomah, S., \& Azizah, N. (2013). Penerapan Metode Blended Learning Berbasis Ict Untuk Meningkatkan Minat Dan Prestasi Belajar Pada Mata Kuliah Ilmu Sosial Budaya Dasar (Isbd) Di Prodi D-lii Kebidanan Fik Unipdu Jombang. Jurnal Eduhealth, 3(2), 103-113.

Mahase, E. (2020). Coronavirus : covid-19 has killed more people than SARS and MERS combined, despite lower case fatality rate. The BMJ, 2(1), 150-159. https://doi.org/10.1136/bmj.m641

Marzal, J. (2014). Studi Penggunaan Jejaring Sosial Edmodo Sebagai Media E-Learning Oleh Dosen Senior Yang Tidak Terbiasa Bekerja Dengan Komputer Jefri. Edumatica, 4(1), 37-43.

Monalisa, \& Havid Ardi. (2013). Using Edmodo Educational Social Network In Teaching English For High School Sudents. Journal of English Language Teaching, 2(1), 220-225.

Nu'man, A. Z. (2013). Efektifitas Penerapan E-Learning Model Edmodo Dalam Pembelajaran Pendidikan Agama Islam Terhadap Hasil Belajar Siswa (Studi Kasus : Smk Muhammadiyah 1 Sukoharjo). Journal of Chemical Information and Modeling, 53(9), 1689-1699. https://doi.org/10.1017/СBO9781107415324.004

Parray, owais. (2017). Indonesia Jobs Outlook 2017. Jakarta: International Labour Organization.

Pratiwi, N. (2015). Pengaruh Tingkat Pendidikan, Perhatian Orang Tua, dan Minat Belajar Siswa Terhadap Prestasi Belajar Bahasa Indonesia Siswa SMK Kesehatan di Kota Tangerang Noor. Jurnal Pujangga, 1(2), 75-105.

Putranti, N. (2013). Cara Membuat Media Pembelajaran Online. Jurnal Pendidikan Informatika Dan Sains, 2(2), 139-147.

Rahmadani, N., \& Anugraheni, I. (2017). Peningkatan Aktivitas Belajar Matematika Melalui Pendektan Problem Based Learning Bagi Siswa Kelas 4 SD. Jurnal Pendidikan Dan Kebudayaan, 7(3), 241-250.

Rosdiana, R. (2018). Penggunaan Media Pembelajaran Berbasis ICT Dan Pengaruhnya Terhadap Tingkat Kelulusan Ujian Nasional Siswa Pada Sekolah Menengah Di Kota Palopo (Studi Kasus Di 5 Sekolah Menengah Di Kota Palopo). Al-Khwarizmi: Jurnal Pendidikan Matematika Dan IImu Pengetahuan Alam, 4(1), 73-82. https://doi.org/10.24256/jpmipa.v4i1.253

Saugi, W. (2018). The Effectiveness of E-LearningUsing Edmodo at Islamic Higher Education(PTKI) in East Kalimantan. Southeast Asian Journal of Islamic Education, 59(01), 59-72.

Sudarman. (2007). Problem Based Learning : Suatu Model Pembelajaran untuk Mengembangkan dan Meningkatkan Kemampuan Memecahkan Masalah. JURNAL PENDIDIKAN INOVATIF, 2(2), 6873.

Sugiyono. (2013). Metode Penelitian Manajemen. Bandung: Alfabeta.

Suparya, I. (2020). Peningkatan Motivasi Dan Kemampuan Berpikir Kritis Mahasiswa Melalui Model Pembelajaran Berbasis Masalah Berbantuan Media Edmodo. Jurnal IImiah Pendidikan Citra Bakti, 07(1), 1-12.

Vania, P. F., Setiawan, W., Fany, A., \& Wijaya, C. (2018). Edmodo as Web-Based Learning to Improve Student 's Cognitive and Motivation in Learning Thermal Physics. Journal of Science Learning, 1(3), 110-115. https://doi.org/10.17509/jsl.v1i3.11796

Wicaksana, E.J, Maridi., S. S. (2017). Efektivitas Modul Pembelajaran Biologi Berorientasi Integrated Scientific Process Untuk Meningkatkan Vocational Skills Siswa Sma. Jurnal Pendidikan Biologi, 8(2), 64-69. Retrieved from http://journal2.um.ac.id/index.php/jpb/issue/view/253

Wicaksana, E.J., A. P. (2020). Efektifitas Pembelajaran Menggunakan Moodle Terhadap Motivasi Dan Minat Bakat. EduTeach, 1(2), 117-124. https://doi.org/https://doi.org/10.37859/eduteach

Wicaksana, E. J., \& Pramana, A. (2018). Analysis of the Impact of Teacher Program Direktorat PSMK ( SM3T Program ) to Animo Learning Students in Biological Lessons In SMKN 1 Kintamani , Bali ( Analysis of the Impact of Teacher Program Direktorat PSMK ( SM3T Program ) to Animo Learning Students. Biodik, 4(2), 77-82. Retrieved from https://online-journal.unja.ac.id/biodik

Yazdi, muhammad. (2012). E-learning sebagai Media Pembelajaran Interaktif Berbasis teknologi Informasi. Jurnal Ilmua Foristek, 2(1), 143-152. 
Yustinaningrum, B. (2018). The Implementation of E-Learning Web-based Model Centric Course (Edmodo) toward The Mathematics' Interest and Learning Outcomes Bettri. Jurnal Pendidikan Matematika, 9(1), 25-32. 